\title{
Changes in mRNAs encoding steroidogenic acute regulatory protein, steroidogenic enzymes and receptors for gonadotropins during spermatogenesis in rainbow trout testes
}

\author{
M Kusakabe ${ }^{1}$, I Nakamura ${ }^{1}$, J Evans ${ }^{2}$, P Swanson ${ }^{3,4}$ \\ and G Young ${ }^{1,4}$ \\ ${ }^{1}$ School of Aquatic and Fishery Sciences, University of Washington, 1140 Boat Street NE, Seattle, Washington 98195-5020, USA \\ ${ }^{2}$ Department of Zoology, University of Otago, PO Box 56, Dunedin, New Zealand \\ ${ }^{3}$ Northwest Fisheries Science Center, NOAA Fisheries, Seattle, Washington 98112, USA \\ ${ }^{4}$ Center for Reproductive Biology, Washington State University, Pullman, Washington 99164, USA \\ (Requests for offprints should be addressed to G Young at the School of Aquatic and Fishery Sciences, University of Washington; \\ Email: grahamy@u.washington.edu)
}

\begin{abstract}
In vertebrates, sperm development and maturation are directly regulated by gonadal steroid hormone secretion. The relationships among the expression of genes encoding steroidogenic proteins and receptors for gonadotropins, and testicular steroid production have not yet been comprehensively determined in male teleosts. In this study, the changes in levels of mRNAs encoding follicle-stimulating hormone (FSH) receptor, luteinizing hormone ( $\mathrm{LH})$ receptor, steroidogenic acute regulatory protein (StAR), cytochrome P450 cholesterol side-chain cleavage, $3 \beta$-hydroxysteroid dehydrogenase/ $\triangle 5$-4-isomerase, cytochrome P450 17 $\alpha$-hydroxylase/17,20-lyase, cytochrome

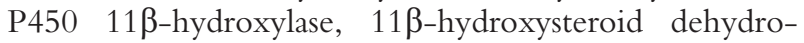
genase and 20 $\beta$-hydroxysteroid dehydrogenase were determined by real-time, quantitative PCR assays and related to changes in serum steroid levels throughout the reproductive cycle in male rainbow trout. Serum 11 -ketotestosterone and $17 \alpha, 20 \beta$-dihydroxy-4-pregnen-
\end{abstract}

3-one levels were measured by RIA. Although the pattern of change in the mRNA levels for the enzymes was variable, the increases in steroidogenic enzyme mRNAs started prior to a significant increase of serum steroid levels. The patterns of transcript levels of FSH and LH receptors suggest that changes in StAR and steroidogenic enzyme transcripts are largely mediated by the FSH receptor during early and mid-spermatogenesis and by the $\mathrm{LH}$ receptor during late spermatogenesis and spermiation. Levels of StAR (10-fold) and P450 17 $\alpha$-hydroxylase/ 17,20-lyase (sevenfold) transcripts changed with the greatest magnitude and were closely related to the changes in serum steroids, suggesting that changes in StAR and P450 $17 \alpha$-hydroxylase/17,20-lyase abundance are likely to be the major influences on overall steroidogenic output during the reproductive cycle in male rainbow trout.

Journal of Endocrinology (2006) 189, 541-554

\section{Introduction}

In vertebrates, two types of gonadotropins (GTHs), follicle-stimulating hormone (FSH) and luteinizing hormone (LH), and gonadal steroid hormones have major roles in the regulation of spermatogenesis and sperm maturation. In mammals, FSH and $\mathrm{LH}$ primarily regulate steroid production through control of steroidogenic enzyme gene expression (Richards 1994). Binding of FSH or LH to their specific cell-surface receptors leads to the production of second messenger molecules which initiate changes in expression and activity of key steroidogenic enzymes for the synthesis of specific steroid hormones at specific times.
In teleosts, two distinct pituitary GTHs, GTH I and GTH II, were first isolated from chum salmon (Suzuki et al. 1988) and coho salmon (Swanson et al. 1991). Later studies demonstrated that GTH I and GTH II are structurally and functionally similar to FSH and $\mathrm{LH}$, and therefore GTH I and GTH II are currently recognized as FSH and LH respectively (Swanson et al. 1989, Van der Kraak et al. 1992, Koide et al. 1993, Tanaka et al. 1993, Okada et al. 1994, García-Hernández et al. 1997, Weltzien et al. 2003). In male rainbow trout, FSH in plasma was elevated during mid-spermatogenesis, whereas LH showed a significant increase in plasma during the spermiating stage (Prat et al. 1996, Gomez et al. 1999). For salmon testis in vitro, the relative potencies of FSH and $\mathrm{LH}$ 
in stimulating steroid synthesis did not change before the late spermatogenesis stage and spermiation (Planas \& Swanson 1995). However, during the later stages of spermatogenesis and spermiation, the sensitivity of the testis to the steroidogenic effects of $\mathrm{LH}$ on progestogen production increased, whereas the sensitivity of the testis to the effects of FSH decreased (Planas \& Swanson 1995). These results imply that the differences in the steroidogenic actions of FSH and $\mathrm{LH}$ that are associated with particular stages of gonadal development are probably due to changes in expression of genes encoding their receptors. Although cDNAs for the FSH receptor (FSH-R) and the $\mathrm{LH}$ receptor (LH-R) have been isolated from several salmonid FSH-R - amago salmon (Oba et al. 1999a), rainbow trout (GenBank accession no. AF439405) and Atlantic salmon (GenBank accession no. AJ567667) - and LH-R - amago salmon (Oba et al. 1999b), rainbow trout (GenBank accession no. AF439404) and Atlantic salmon (GenBank accession no. AJ579790) - the intracellular mechanisms of steroidogenesis that are regulated by FSH and LH through their receptors in teleosts are not understood to the same degree as in mammals.

For male salmonids, the potent androgen, 11-ketotestosterone (11-KT) and the progestogen, $17 \alpha, 20 \beta$ dihydroxy-4-pregnen-3-one (17,20 $\beta$-P), have key roles in the regulation of spermatogenesis. A distinct shift in the steroidogenic pathway from $11-\mathrm{KT}$ to $17,20 \beta-\mathrm{P}$ synthesis occurs in the testes of salmonid species around the onset of spermiation (Nagahama 1994). Studies on male salmonids indicate that spermiation is associated with a decrease in plasma 11-KT and an increase in plasma 17,20 $\beta-\mathrm{P}$ (Baynes \& Scott 1985, Lou et al. 1986, King \& Young 2001). Using Japanese eel testis fragments in vitro, Miura et al. (1991) demonstrated that 11-KT can induce all stages of spermatogenesis, including spermatogonial proliferation, meiotic division and spermiogenesis. These results indicate that $11-\mathrm{KT}$ has important roles during spermatogenesis in teleost species (Schulz \& Miura 2002). Although the capacity of the testis to produce $17,20 \beta-\mathrm{P}$ is low during spermatogenesis, 17,20 $\beta-\mathrm{P}$ production sharply increases during spermiation (Ueda et al. 1983, 1984, Sakai et al. 1989). Two successive injections of 17,20 $\beta-P$ induced precocious spermiation in nonspermiating amago salmon and goldfish (Ueda et al. 1985). These results suggest that $17,20 \beta-\mathrm{P}$ plays a role in the process of final sperm maturation and spermiation in teleosts.

Previous studies have shown that the long-term changes in steroid secretion in mammalian ovaries are regulated by changes in steroidogenic enzyme gene expression (Doody et al. 1990a, 1990b, Aspden et al. 1998). It is likely that steroid hormone synthesis in teleosts is similarly regulated by changes in the activity of individual steroidogenic enzymes through the action of GTHs and/or endogenous steroids. Salmonids are excellent study animals to examine the changes in steroidogenic enzyme gene expression in relation to steroid hormone synthesis, since germ cell development progresses in a synchronous fashion and dynamic changes in steroid hormone secretion occur during gametogenesis. In rainbow trout, cDNAs for most of the steroidogenic enzymes responsible for the synthesis of sex steroids have already been isolated: cytochrome P450 cholesterol side-chain cleavage (P450scc) (Takahashi et al. 1993), cytochrome P450 17 $\beta$ hydroxylase/17,20-lyase (P450C17) (Sakai et al. 1992), $3 \beta$-hydroxysteroid dehydrogenase/ $\triangle 5-4$-isomerase $(3 \beta$ HSD) (Sakai et al. 1994), cytochrome P450 aromatase (P450 arom) (Tanaka et al. 1992), cytochrome $\mathrm{P} 450$ $11 \beta$-hydroxylase (P45011 $\beta$ ) (Liu et al. 2000, Kusakabe et al. 2002a), 11 $\beta$-hydroxysteroid dehydrogenase (11 $\beta$ HSD) (Kusakabe et al. 2003) and 20 $\beta$-hydroxysteroid dehydrogenase (20ß-HSD) (Guan et al. 1999). Recent studies reported changes in mRNA levels for key ovarian steroidogenic enzymes during a reproductive cycle in channel catfish (Kumar et al. 2000), Arctic char (von Hofsten et al. 2002) and rainbow trout (Nakamura et al. 2005), and a few recent studies in male teleosts reported seasonal changes in transcript levels of a single steroidogenic enzyme (Liu et al. 2000, Kusakabe et al. 2002a, 2003). However, comprehensive studies on the expression of testicular steroidogenic enzyme genes during spermatogenesis in teleosts have not been reported.

The rate-limiting step of tropic hormone-induced steroidogenesis in mammals is the rate of the delivery of cholesterol to P450scc by steroidogenic acute regulatory protein (StAR) (Stocco 2000). Studies on mammalian StARs have mainly concentrated on the short-term (acute) changes in steroidogenesis with little information available on the regulation of StAR during prolonged seasonal cycles. Recently, cDNAs encoding StAR in brook trout and rainbow trout were isolated (Kusakabe et al. 2002b), and an increase in ovarian StAR gene expression during the late vitellogenesis, maturation and post-ovulatory stages in rainbow trout was demonstrated (Bobe et al. 2004, Nakamura et al. 2005). However, the changes occurring in testicular StAR gene expression in teleosts during spermatogenesis remain to be determined.

The aim of this study was to determine the changes in expression of the gene encoding steroidogenic enzymes and StAR in rainbow trout testes during spermatogenesis in relation to androgens and $17,20 \beta-\mathrm{P}$ production, and to changes in mRNAs encoding FSH-R and LH-R. In the course of the study, we also had to address the problem of normalization of mRNA levels by expression of housekeeping genes. The trout testis changes 20-fold in size during spermatogenesis and has proven to be problematic in this regard. Kusakabe et al. (2002a) reported the progressive reduction of mRNA levels for the commonly used housekeeping gene, $\beta$-actin, during midspermatogenesis. In this study, we conducted further investigations of the stability of two other housekeeping genes, acidic ribosomal phosphoprotein P0 (ARP) and $18 \mathrm{~S}$ ribosomal RNA. 


\section{Materials and Methods}

\section{Study animals}

Two-year-old, male rainbow trout were obtained monthly from Wanaka Trout Hatchery (Wanaka, New Zealand) from January to November in 2001. For each sampling, 3-5 fish were anesthetized with $300 \mathrm{mg} / 1$ MS222 (3-aminobenzoic acid ethyl ester; Sigma) buffered in sodium bicarbonate. Testes were isolated by dissection, and blood was sampled from the caudal vein with syringes. Blood was allowed to clot, and serum was obtained by centrifugation and stored at $-20{ }^{\circ} \mathrm{C}$ for steroid assay. Testis fragments were frozen with liquid nitrogen and stored at $-80{ }^{\circ} \mathrm{C}$ for RNA extraction. Testis fragments were also fixed with Bouin's fixative to determine the developmental stage. Animal care and use were approved by the University of Otago Committee on Care and Use of Animals.

\section{Histologic analysis of rainbow trout testes}

The fixed testis fragments were dehydrated and embedded in paraffin, sections $(8 \mu \mathrm{m})$ were stained by hematoxylin and eosin, and the developmental stages in each sample were determined, according to Grier (1981), as follows:

1. Early spermatogenesis - spermatogonia and spermatocytes are dominant.

2. Mid-spermatogenesis - spermatogonia, spermatocytes, spermatids and sperm are present.

3. Late spermatogenesis - sperm become dominant and very few spermatogonia and/or spermatocytes are present.

4. After spawning - the testes size declines and no developing germ cells are present.

\section{Serum sex steroids}

Sex steroids were extracted from serum with ethyl ether, as previously described by Kagawa et al. (1981). Levels of $11-\mathrm{KT}$ and $17 \alpha, 20 \beta-\mathrm{P}$ were measured by RIA, as previously described (Kagawa et al. 1981, Ueda et al. 1985, Young et al. 1986).

\section{Expression of genes encoding steroidogenic proteins and gonadotropin receptors}

Previous studies have shown that the sites of expression of steroidogenic enzymes and StAR in rainbow trout testes are restricted to Leydig cells (Kobayashi et al. 1998, Kusakabe et al. 2002a, 2002b, 2003). Furthermore, the localization of Leydig cells in testis during spermatogenesis changes with the maturational stage (Kusakabe et al. 2003). Therefore, in order to avoid biasing the number of Leydig cells in each sample, testes samples for RNA extraction were collected as $300 \mathrm{mg}$ cross-sections taken from the widest point, approximately $3 \mathrm{~cm}$ from the anterior end. Testis fragments from 3-5 males were collected for each month. Relative expression of transcripts was measured by real-time, quantitative RT-PCR as described below.

Total RNA was isolated from the testis fragments with Trizol reagent, as described by the manufacturer (Invitrogen). Concentrations of total RNA were carefully measured at least three times with NanoDrop ND-100 (NanoDrop Technologies, Wilmington, DE, USA), and equal amounts of RNA were subjected to reverse transcription to synthesize cDNAs.

An amount of $300 \mathrm{ng}$ total RNA was incubated with $0 \cdot 6$ unit of DNase I, Amp Grade (Invitrogen) at room temperature for $15 \mathrm{~min}$ to eliminate genomic DNA contamination. DNase I was inactivated by heat denaturation at $65^{\circ} \mathrm{C}$ for $10 \mathrm{~min}$. Subsequently, single-strand $\mathrm{cDNAs}$ were synthesized from the DNase I-treated RNA with the High-Capacity cDNA archive kit as described by the manufacturer (Applied Biosystems, Foster City, CA, USA).

For the relative quantitation of StAR, steroidogenic enzyme and GTH receptor gene expression, real-time, quantitative RT-PCR was performed with the ABI PRISM 7300 sequence detection system (Applied Biosystems). Primers and TaqMan probes for real-time PCR were designed with Primer Express, Version 1.5 (Applied Biosystems). The nucleotide sequences for the primers and probes are listed in Table 1. For normalization of data, an $18 \mathrm{~S}$ ribosomal gene was measured with commercially available primers and probes purchased from Applied Biosystems.

Each real-time PCR reaction contained $25 \mu \mathrm{l}$ PCR mixture made from $12.5 \mu \mathrm{l}$ ABI Universal PCR Master Mix, $0.9 \mu \mathrm{M}$ forward primer, $0.9 \mu \mathrm{M}$ reverse primer, $0 \cdot 2 \mu \mathrm{M}$ fluorescent-labeled probe and $3 \cdot 0 \mu \mathrm{lDNA}$ template. Real-time PCR cycling conditions were $50{ }^{\circ} \mathrm{C}$ for $2 \mathrm{~min}$ and $95^{\circ} \mathrm{C}$ for $10 \mathrm{~min}$, followed by 45 cycles of $95{ }^{\circ} \mathrm{C}$ for $15 \mathrm{~s}$ and $60{ }^{\circ} \mathrm{C}$ for $1 \mathrm{~min}$. A standard curve was generated by serial dilutions of cDNA for each PCR reaction to determine the levels of transcripts. Standard curve dilutions were run in triplicate, and correlation coefficients of the standard curves ranged from 0.99 to 1.00. RNA samples not subject to reverse transcription were used to check for genomic DNA contamination during RNA preparation.

In order to present changes in steroidogenic enzyme and StAR mRNA levels on the basis of absolute amounts per testes, the total testes weight in each fish and the weight of frozen tissue used for total RNA extraction were measured. The yield of total RNA extracted from each testis sample was calculated by measuring the concentration of total RNA. Therefore, it was possible to estimate the total amount of total RNA contained within the testes. Given the result obtained from real-time PCR in the formula, the relative amount of target mRNA per animal normalized to relative gonad size was determined by the following formula: 

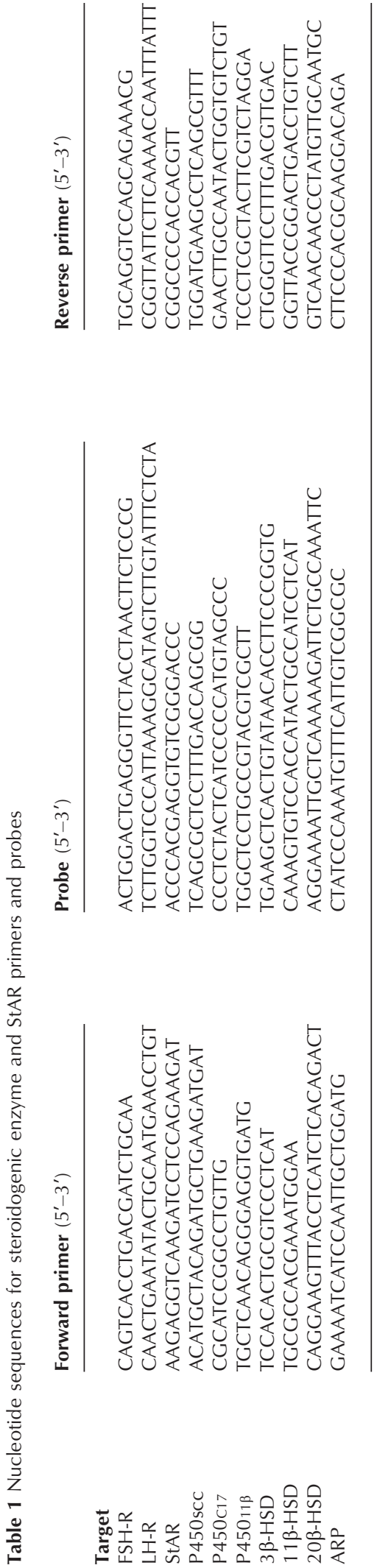

Target mRNA levels $=\frac{\text { real-time PCR value }}{18 \mathrm{~S}}$ $\times \frac{\text { total RNA amount from RNA extraction }}{\text { tissue weight for RNA extraction }}$ $\times \frac{\text { gonad weight }}{\text { body weight }}$

Data are presented as relative mRNA levels. Mean of initial samples in January 2001 was set as 1 .

\section{Statistical analysis}

Serum steroid hormones, FSH-R, LH-R, StAR and steroidogenic enzyme mRNA levels were analyzed by one-way ANOVA followed by the Fisher PLSD test. The data were $\log$ transformed where appropriate before analysis to obtain approximately normal distributions. For the sake of clarity, not all significant differences are shown on graphs. Instead, only prominent increases or decreases are indicated. Linear regression analysis was used to examine relationships between serum steroid hormone levels and GTH receptors, StAR and steroidogenic enzyme mRNA levels, and the relationship between GTH receptor mRNA levels and StAR or steroidogenic enzyme mRNA levels.

\section{Results}

Changes in gonadosomatic index (GSI)

Changes in GSI (gonad weight/body weight $\times 100$ ) from January to November 2001 are shown in Fig. 1. The GSI was maintained at low levels during the early spermatogenesis in January $(0 \cdot 2 \% \pm 0 \cdot 07)$ and February $(0 \cdot 4 \% \pm$ $0 \cdot 07)$. The GSI increased significantly $(P<0 \cdot 0001)$ to a peak in March (3.5\% $\pm 0 \cdot 82)$. High GSI values (2.5-3.5\%) were maintained during mid-spermatogenesis and gradually declined during the late spermatogenesis. The GSI in November $(0 \cdot 6 \% \pm 0 \cdot 12)$ decreased to the same levels as the early spermatogenesis.

\section{Changes in size and structure of testes}

Representative sections of testes in each month (Fig. 2) 1. Early spermatogenesis (January-February). Spermatogonia and spermatocytes were dominant in January. In February, more spermatocytes and spermatids appeared and a few sperm were first observed. The size of the cross-sections continuously increased from January to February.

2. Mid-spermatogenesis (March-June). In March, small clusters of spermatozoa were observed in the center of cysts, although spermatocytes and spermatids were still dominant. The incidence of spermatocytes and spermatids 


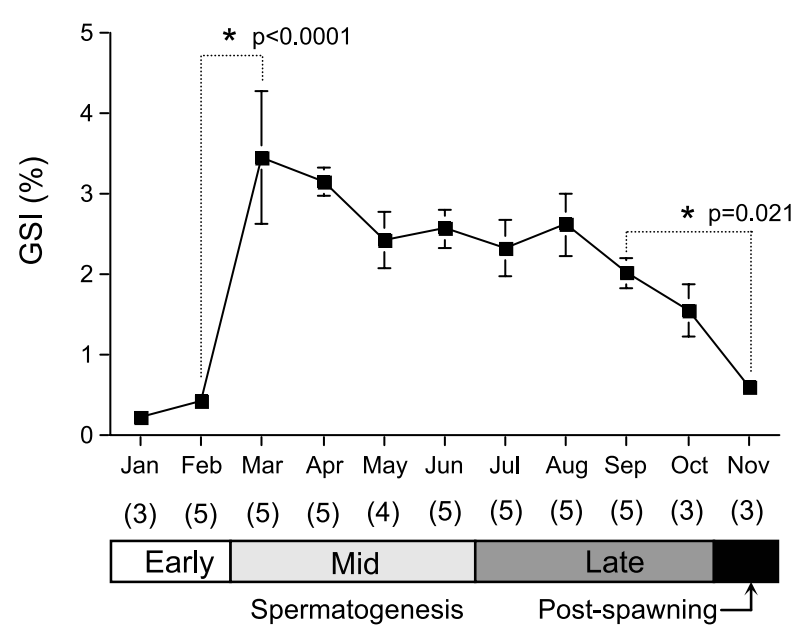

Figure 1 Changes in gonadosomatic index (GSI; gonad weight/body weight $\times 100$ ) during spermatogenesis. Data are shown as the mean \pm S.E. Number of samples per data point is shown in parentheses. One-way ANOVA was performed $(P<0 \cdot 0001)$. Significant differences identified by ANOVA and Fisher PLSD test are indicated.

declined continuously from April to June, while numbers of spermatozoa increased. Cross-sectional area of testes appeared to become maximal during this stage when the mean GSI reached maximum levels.

3. Late spermatogenesis (July-October). Sperm became dominant, and very few spermatocytes or spermatids were observed during late spermatogenesis stage (JulyOctober). Spermiation occurred in August-October, as evidenced by breakdown of cyst walls and ability to collect sperm with gentle abdominal pressure. The area of crosssections appeared to decrease at the end of the late spermatogenesis stage (October), when mean GSI also declined.

4. Post-spawning (November). The size of testes dramatically declined because of sperm release in November. The amount of sperm decreased, and spermatogonia and connective tissue occupied the rest of the cross-sectional areas.

\section{Seasonal changes in serum steroid levels}

Serum 11-KT levels Serum 11-KT levels (Fig. 3A) were low during early and mid-spermatogenesis $(5-7 \mathrm{ng} / \mathrm{ml}$, January-April), increased significantly $(P=0.0001)$ in the mid-spermatogenesis stage from May $(17 \cdot 76 \pm 1.63 \mathrm{ng} /$ $\mathrm{ml})$ to June $(49 \cdot 15 \pm 8.61 \mathrm{ng} / \mathrm{ml})$, reached a peak during late spermatogenesis $(65.6 \pm 14.3 \mathrm{ng} / \mathrm{ml}$, September), and then decreased significantly to low levels in the post-spawning $(3 \cdot 0 \pm 0 \cdot 7 \mathrm{ng} / \mathrm{ml}$, November $)(P=0 \cdot 0001)$.

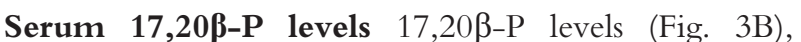
although low, progressively increased from $0.12 \pm$ $0.02 \mathrm{ng} / \mathrm{ml}$ in January (early spermatogenesis) to $0.8 \pm$ $0.4 \mathrm{ng} / \mathrm{ml}$ in June (mid-spermatogenesis). Levels then increased significantly between June and August $(P=0.003)$ and peaked at the late spermatogenesis stage $(16.7 \pm 4 \cdot 2 \mathrm{ng} / \mathrm{ml}$, September $)(P=0 \cdot 0003)$. The elevation in 17,20 $-\mathrm{P}$ levels between July and September occurred when spermiation was evident (Fig. 2). When all testes reached the post-spawning stage in November, $17,20 \beta-P$ levels significantly decreased $(0 \cdot 46 \pm 0 \cdot 1 \mathrm{ng} / \mathrm{ml})$ $(P=0 \cdot 0002)$.

\section{Changes in total RNA amount/testes}

The total RNA amount was estimated from the yield of RNA from $300 \mathrm{mg}$ tissue and total gonad weight (Fig. 4). The levels of total RNA/testes were low $(2 \cdot 5-7 \cdot 0 \mathrm{mg} /$ testis) during the early spermatogenesis in January and February, and increased significantly to the highest levels (32.6-35.5 mg/testes) $(P<0.0001)$ in March and April. The levels of total RNA/testes decreased significantly in May $(16 \cdot 8 \pm 3.7 \mathrm{mg} /$ testes $)(P=0 \cdot 004)$ to reach low levels during late spermatogenesis (July-October, $1 \cdot 7-3 \cdot 3 \mathrm{mg} /$ testis) and the post-spawning period (November, $10 \cdot 6 \pm 1 \cdot 4 \mathrm{mg} /$ testes).

\section{Seasonal changes in ARP $m R N A$ and $18 S$ RNA levels}

The seasonal changes in ARP mRNA and 18S RNA levels during spermatogenesis are presented in Fig. 5. The ARP mRNA levels changed significantly during the sampling period $(P<0 \cdot 0001)$. ARP mRNA levels increased in February and then declined in March. From March to November, the ARP mRNA levels were relatively stable. Notably, the average ARP mRNA levels in February were 3-4 times higher than the levels in the latter half of the study. In contrast, 18S RNA levels were relatively stable through the experimental period and showed no significant differences between sampling points $(P=0 \cdot 105)$.

Seasonal changes in FSH-R, LH-R, StAR, P450sce, P450C17, P45011 $\beta, 3 \beta$-HSD, $11 \beta$-HSD and $20 \beta$-HSD $m R N A$ levels

The transcript levels shown in Fig. 6 were normalized to relative abundance, accounting for total testis mass, RNA yield and body mass by the formula given in Materials and methods. The changes in FSH-R, LH-R, StAR, P450scc, P450C17, P45011 $\beta$, 3 $\beta-H S D, 11 \beta-H S D$ and $20 \beta-H S D$ mRNA levels during spermatogenesis are presented as a ratio of the levels in January. The mean of initial samples in January 2001 was set as 1.

FSH-R Transcript levels of FSH-R fluctuated during the study. Levels increased significantly (approximately threefold) as testes entered mid-spermatogenesis 


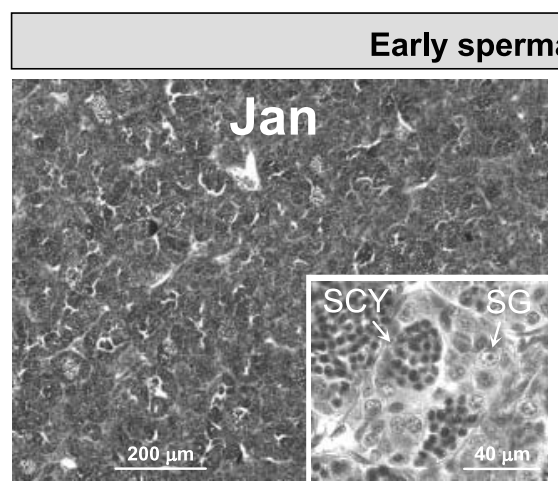

\section{matogenesis}
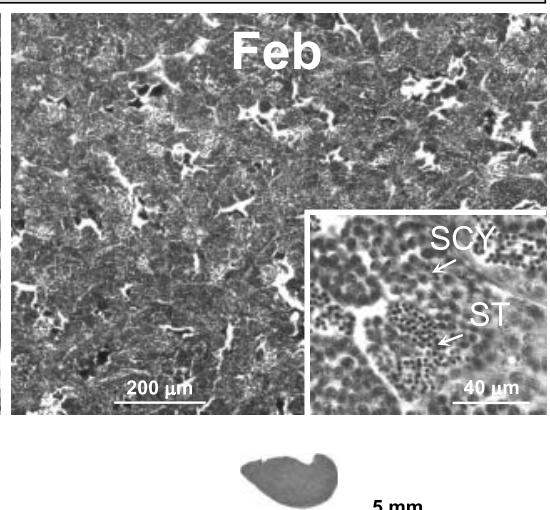

$5 \mathrm{~mm}$

\section{Mid spermatogenesis}
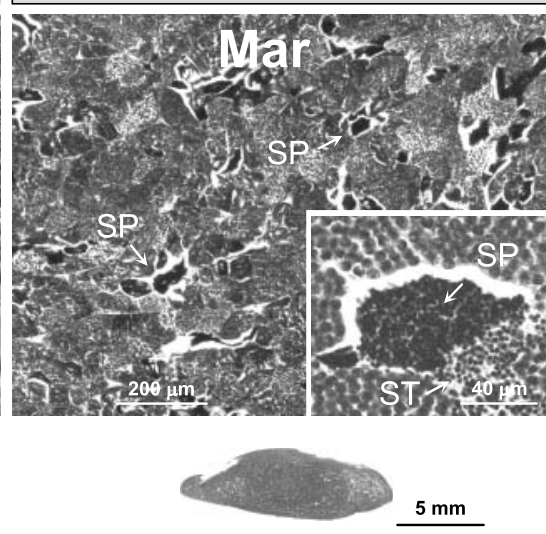

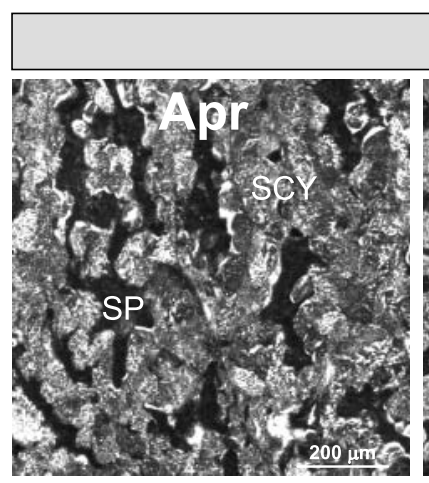

\section{Mid spermatogenesis}
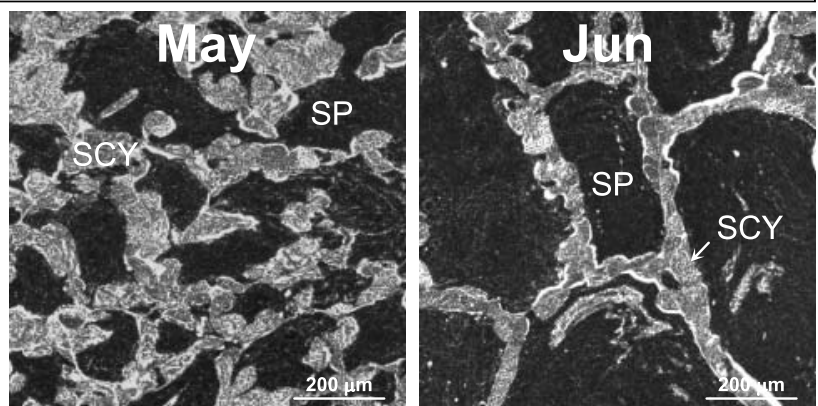

Late spermatogenesis
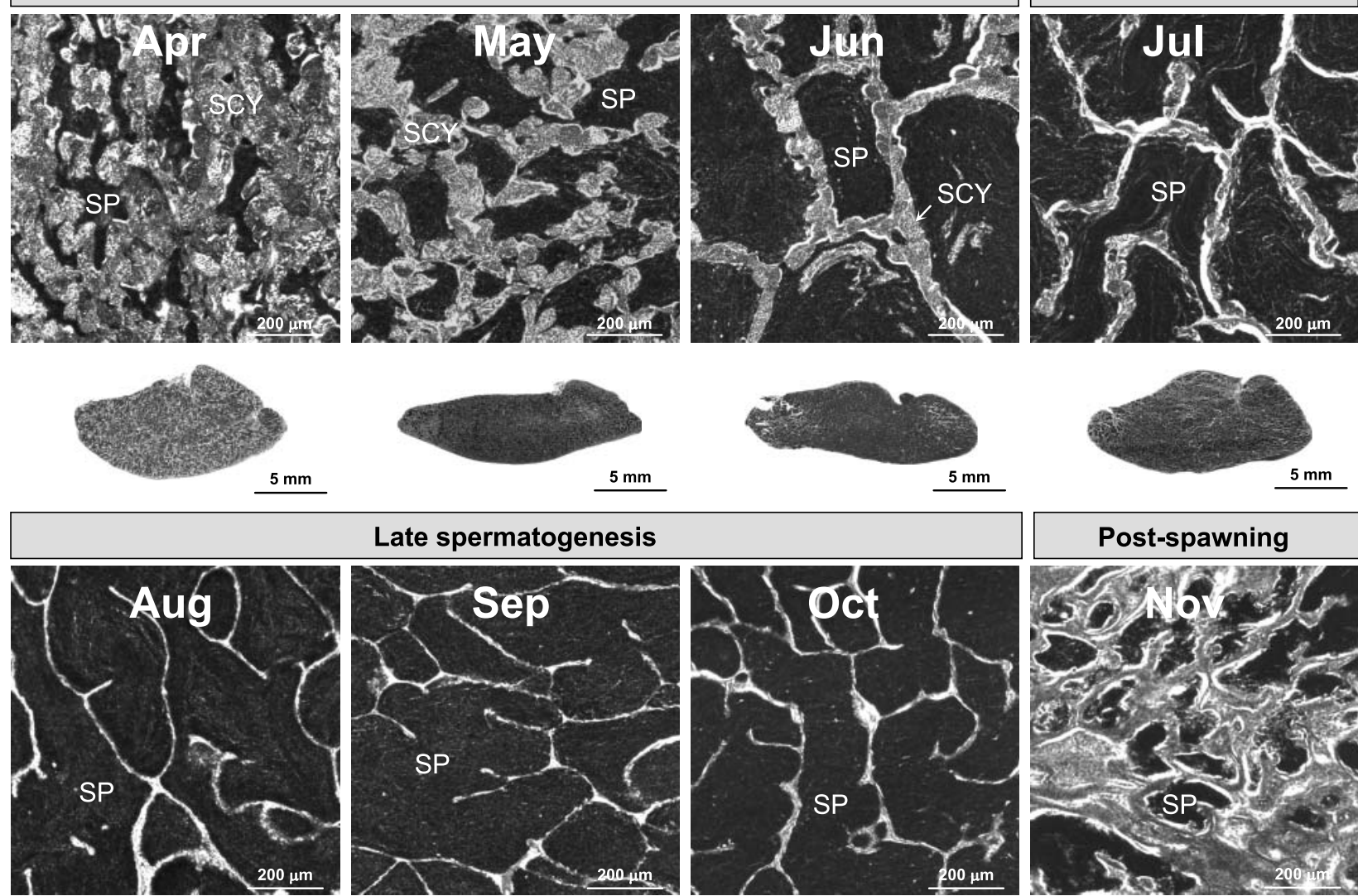

\section{Late spermatogenesis}
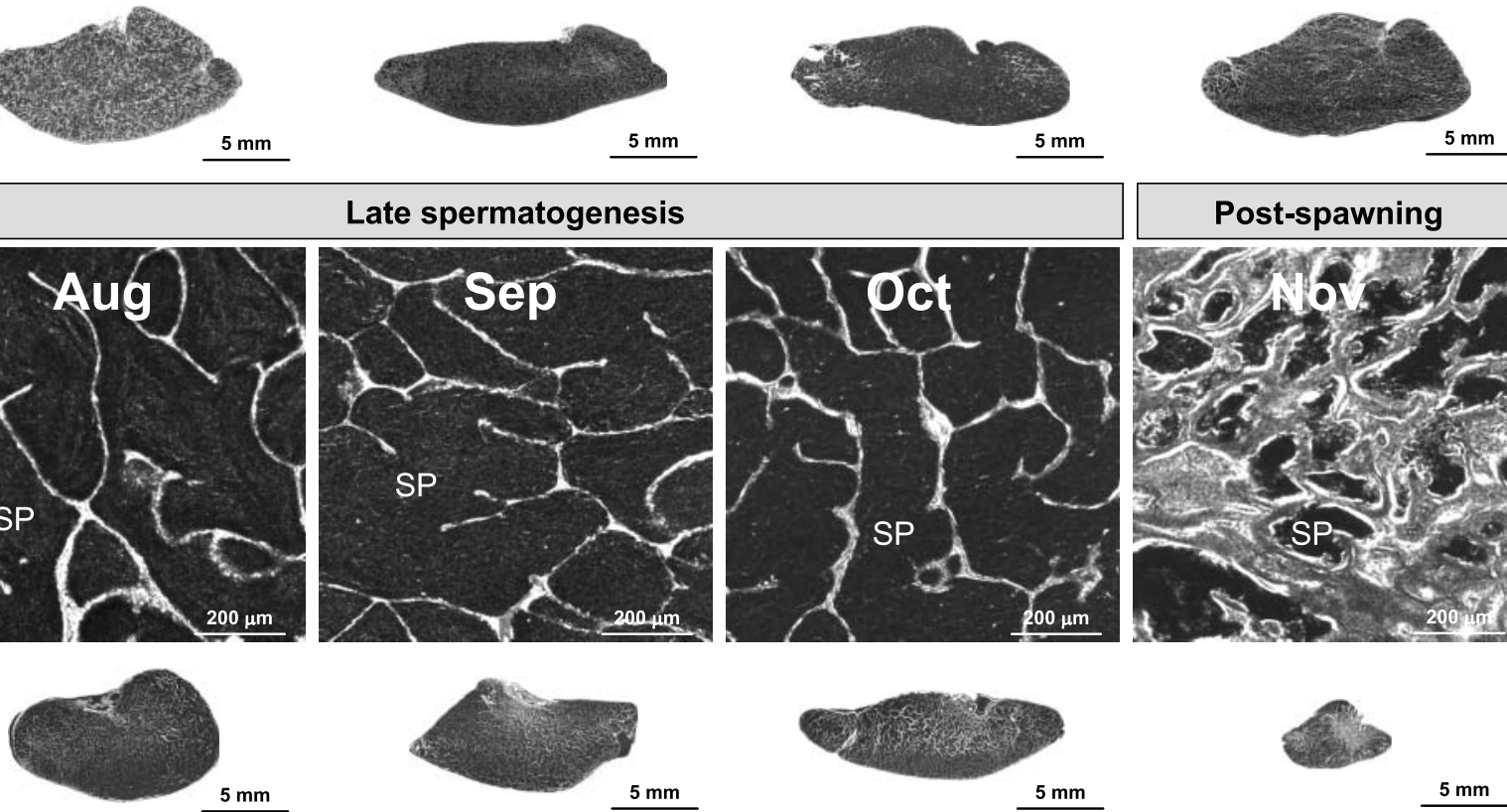

$5 \mathrm{~mm}$

$5 \mathrm{~mm}$

Figure 2 Developmental stages of rainbow trout testes. Representative hematoxylin and eosin-stained sections for each month showing seasonal changes in cell components. SG, spermatogonia; SCY, spermatocyte; ST, spermatid; SP, spermatozoa. 

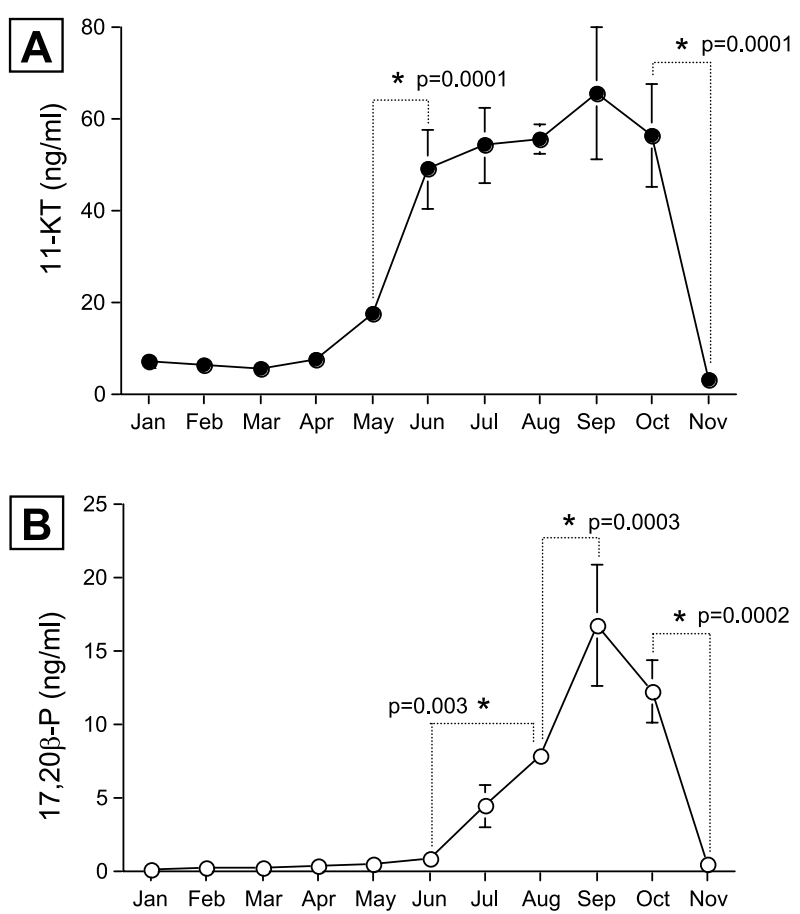

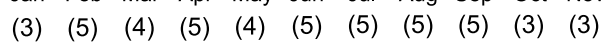

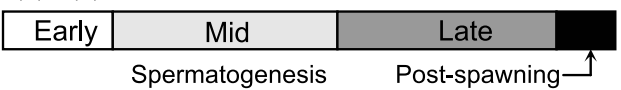

Figure 3 Changes in the $(\mathrm{A})$ serum 11-ketotestosterone (11-KT) and $(B)$ serum $17 \alpha, 20 \beta$ dihydroxy-4-pregnen-3-one (17,20 $\beta$-P) levels of male rainbow trout during spermatogenesis. Data are shown as the mean \pm S.E. Number of samples per data point is shown in parentheses. One-way ANOVA was performed (11-KT, $P<0 \cdot 0001 ; 17,20 \beta-P, P<0 \cdot 0001)$. Significant differences identified by ANOVA and Fisher PLSD test are indicated.

(February-March) $(P=0 \cdot 0002)$. Although other statistical differences were observed, transcript levels varied by only twofold or less for the remainder of the study.

LH-R Levels of LH-R mRNA increased fourfold $(P<0 \cdot 0001)$ between February (early spermatogenesis) and May (mid-spermatogenesis) and twofold $(P=0.039)$ between mid-spermatogenesis and the middle stages of late spermatogenesis (May-August). The second rise in LH-R mRNA occurred during the onset of spermiation (Fig. 2). Transcript levels then slightly decreased in October (late spermatogenesis) and November (post-spawning).

StAR Relative levels of StAR transcripts were lowest during early spermatogenesis (January-February). StAR mRNA levels increased significantly (threefold) in March (mid-spermatogenesis) $(P<0 \cdot 0001)$ and continued to increase until late spermatogenesis (August-September), when serum steroid levels were maximal, and then significantly decreased in October $(P=0.035)$ to reach low levels by the post-spawning period (November).

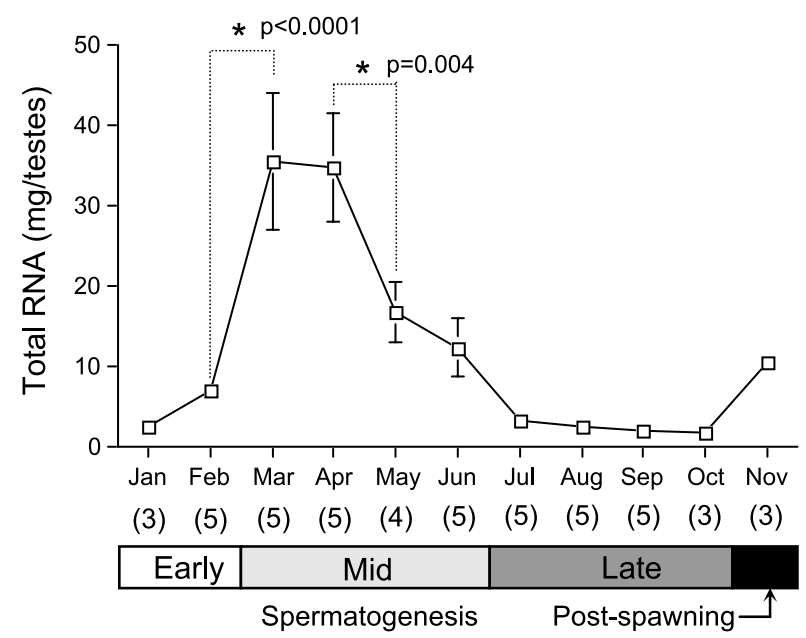

Figure 4 Changes in total RNA amount per fish during spermatogenesis. Data are shown as the mean \pm S.E. Number of samples per data point is shown in parentheses. One-way ANOVA was performed $(P<0 \cdot 0001)$. Significant differences identified by ANOVA and Fisher PLSD test are indicated.

P450scc During early spermatogenesis (JanuaryFebruary), P450scc mRNA levels were low. Gradual, progressive and significant increases occurred between February and September $(P<0 \cdot 0001)$. P450scc mRNA levels declined moderately, but not significantly during the late spermatogenesis (October) to post-spawning period (November).

P450C17 P450C17 mRNA levels were low during early spermatogenesis (January-February). From then on, P450C17 mRNA levels progressively and significantly increased $(P<0 \cdot 0001)$ to a peak during late spermatogenesis (August-September). P450C17 mRNA levels quickly declined in October $(P=0.0034)$, and low levels were maintained in the post-spawning period (November).

P45011及 P45011 $\beta$ mRNA levels were low during early spermatogenesis (January and February), and slightly but significantly increased in March (mid-spermatogenesis) $(P=0.0009)$. Levels were relatively stable until a significant increase $(P=0 \cdot 0044)$ occurred between October (late spermatogenesis) and November (post-spawning).

3 $\beta$-HSD 3 $\beta$-HSD mRNA levels were low during early spermatogenesis (January-February) and significantly increased ninefold $(P<0 \cdot 0001)$ to a peak in March and April (mid-spermatogenesis). The transcript levels then decreased in May $(P=0.0042)$ and were maintained at low levels until post-spawning (November), although levels decreased transiently $(P=0 \cdot 031)$ in October.

11ß-HSD Transcript levels of $11 \beta$-HSD were low during early spermatogenesis (January and February), and 

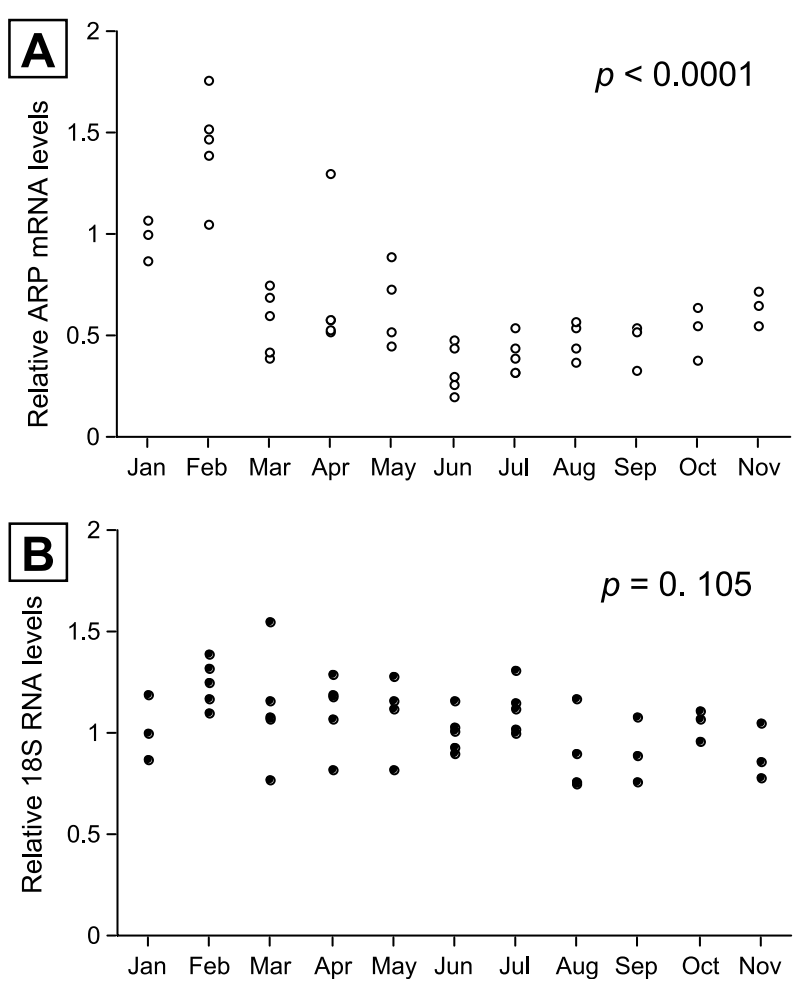

$\begin{array}{lllllllllll}\text { (3) } & \text { (5) } & \text { (5) } & \text { (5) } & \text { (4) } & \text { (5) } & \text { (5) } & \text { (4) } & \text { (3) } & \text { (3) } & \text { (3) }\end{array}$

\begin{tabular}{|c|c|c|}
\hline Early & Mid & Late \\
\hline
\end{tabular}

Figure 5 (A) Changes in mRNA levels of acidic ribosomal phosphoprotein P0 (ARP) and (B) ribosomal 18S RNA during spermatogenesis. The data for ARP mRNA levels were log transformed before analysis to achieve approximately normal distributions. One-way ANOVA was performed (ARP, $P<0 \cdot 0001$; $18 \mathrm{~S}, P=0 \cdot 105)$.

significantly increased in March (mid-spermatogenesis) $(P<0 \cdot 0001)$. Transcript levels then significantly increased approximately threefold during late spermatogenesis from July to August $(P=0 \cdot 014)$, with a significant decline between September and October $(P=0 \cdot 042)$.

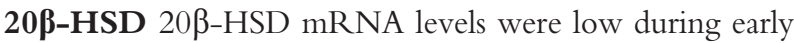
spermatogenesis (January and February), but increased threefold in March $(P=0.0033)$. A slight but significant $(P<0 \cdot 0001)$ decline occurred between March and June. Levels then declined $(P=0.0004)$ to lowest levels in July and were stable until October. Transcript levels in post-spawning testes (November) were significantly elevated $(P<0 \cdot 0001)$.

\section{Regression analysis}

Linear regression analysis (Table 2) identified a moderate but significant relationship between changes in serum 11-KT levels and transcript levels of LH-R $(P<0 \cdot 0001$, $\left.r^{2}=0 \cdot 32\right)$ StAR $\left(P<0 \cdot 0001, \quad r^{2}=0 \cdot 31\right)$ or $\mathrm{P} 450 \mathrm{C} 17$
$\left(P<0 \cdot 0001, r^{2}=0 \cdot 30\right)$. StAR transcript levels were also significantly correlated with serum 17,20 $\beta-P$ levels $\left(P<0 \cdot 0001, r^{2}=0 \cdot 31\right)$. A moderate but significant negative relationship $\left(P=0 \cdot 0002, r^{2}=0 \cdot 29\right)$ existed between serum $17,20 \beta-\mathrm{P}$ and $20 \beta-\mathrm{HSD}$ mRNA. FSH-R mRNA levels were moderately related to StAR, 3 $\beta-\mathrm{HSD}, \mathrm{P} 450 \mathrm{C} 17$ and $\mathrm{P} 45011 \beta$ transcript levels $\left(P<0 \cdot 001,0 \cdot 23<r^{2}<0 \cdot 45\right)$, with a stronger relationship between FSH-R mRNA and P450scc $\left(P<0.0001, r^{2}=0.53\right)$ and $11 \beta-$ HSD $(P<0.0001$, $\left.r^{2}=0 \cdot 72\right)$ transcripts. LH-R transcript levels were strongly related to StAR, P450scc, P450C17 and 11ß-HSD transcripts $\left(P<0 \cdot 0001,0 \cdot 61<r^{2}<0 \cdot 65\right)$ and displayed a moderate relationship with $\mathrm{P} 45011 \beta$ transcript levels $(P<0 \cdot 0001$, $\left.r^{2}=0 \cdot 36\right)$.

\section{Discussion}

Recent studies in female teleosts have demonstrated seasonal changes in mRNA levels encoding key steroidogenic enzymes and StAR (Kumar et al. 2000, Nakamura et al. 2005). However, a comprehensive understanding of the pattern changes in expression of GTH receptors, StAR and steroidogenic enzymes is limited in male teleosts. In this study, we determined the seasonal changes in FSH-R, LH-R, StAR and six steroidogenic enzymes

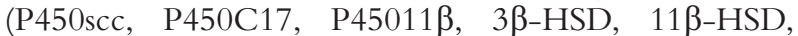
$20 \beta-H S D)$ mRNA levels in male rainbow trout.

Before discussing these changes, the issue of the use of housekeeping genes for tissues that exhibit significant changes in size and cellular components, such as teleost gonads, needs to be addressed. Rainbow trout testes changed 20-fold in mass during the course of this study, for example. Normalization of RNA levels using housekeeping genes is commonly used to verify the amount of starting materials and efficiency in reverse transcription and PCR reactions. The usage of housekeeping genes is currently controversial and recently has been discussed by Bustin (2002). Previously, we reported significant changes in transcripts for $\beta$-actin, a classical housekeeping gene, during the reproductive cycle of male rainbow trout (Kusakabe et al. 2002a). In this study, we conducted further investigations of the stability of two other commonly used housekeeping genes, ARP mRNA and $18 \mathrm{~S}$ ribosomal RNA. ARP mRNA levels changed significantly during spermatogenesis, similar to $\beta$-actin transcripts, with a greater than threefold difference between the highest (February) and lowest (June) levels, whereas $18 \mathrm{~S}$ ribosomal RNA showed no significant changes through the reproductive cycle (Fig. 5). Therefore, we used $18 \mathrm{~S}$ ribosomal RNA as an internal control gene.

In this study, the GSI of the male rainbow trout increased 17-fold from January to March, followed by a prolonged gradual decrease for the remainder of the study (Fig. 1). The cellular composition of testes also underwent dramatic changes (Fig. 2). These changes in size and 

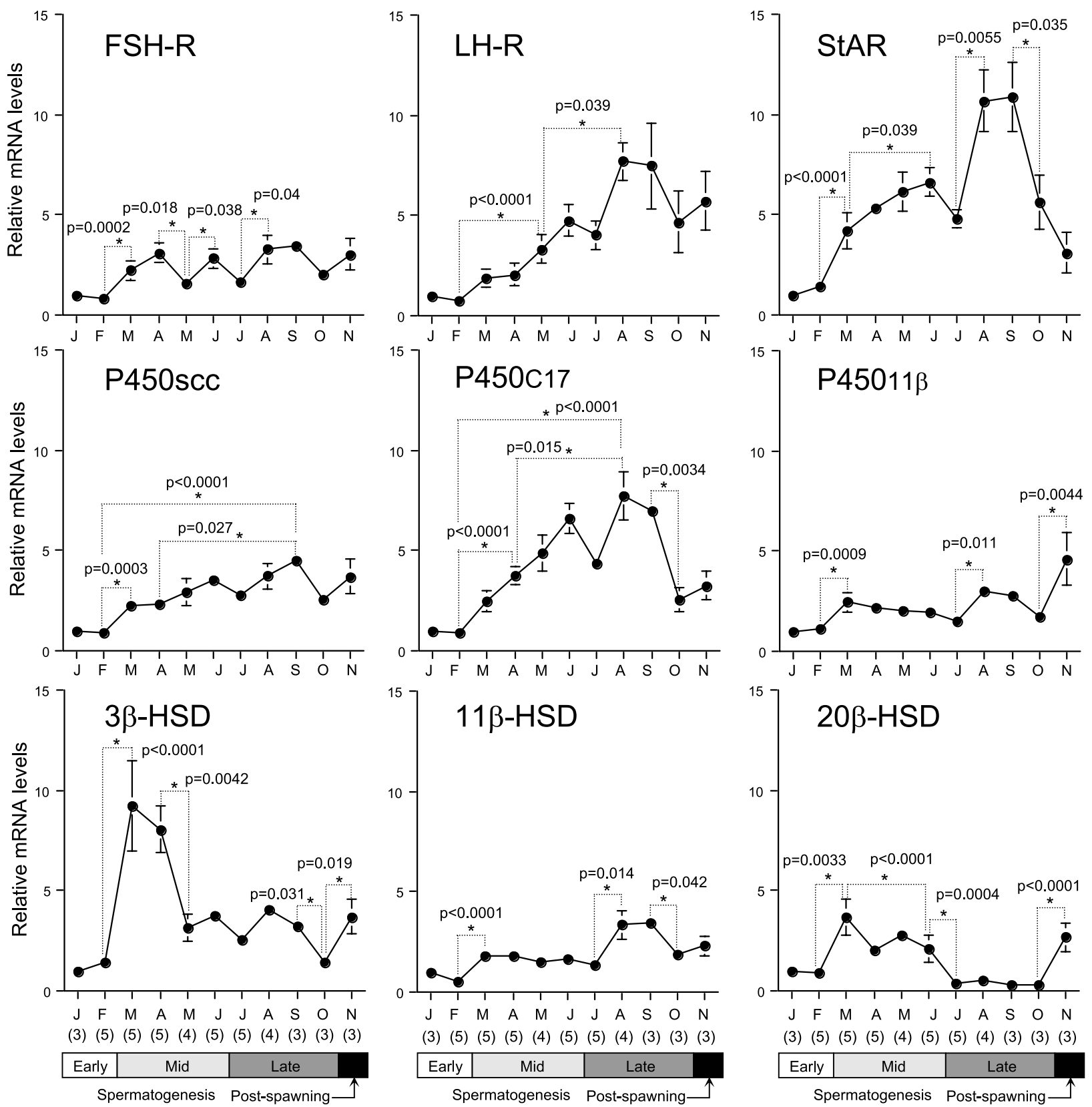

Figure 6 Changes in mRNA levels of FSH-R, LH-R, StAR, P450scc, P450C17, P45011 $\beta, 3 \beta-H S D, 11 \beta-H S D$ and 20 $\beta$-HSD during spermatogenesis. Data are shown as the mean \pm S.E., and expressed as relative abundance accounting for total testis mass, RNA recovery and body mass (see Materials and Methods). Number of samples per data point is shown in parentheses. All the data were log transformed before analysis to achieve approximately normal distributions. One-way ANOVA was performed (FSH-R, $P=0 \cdot 0008$; LH-R, $P<0.0001 ;$ StAR, $P<0 \cdot 0001 ; P 450$ scc, $P<0 \cdot 0001 ; P 450 C 17, P<0 \cdot 0001 ; P 45011 \beta, P<0 \cdot 0001 ; 3 \beta-H S D, P<0 \cdot 0001 ; 11 \beta-H S D, P<0 \cdot 0001$; $20 \beta-H S D, P<0 \cdot 0001)$. Significant differences identified by ANOVA and Fisher PLSD test are indicated.

composition were accompanied by a significant pattern of change in the amount of total RNA per testes, which varied 30-fold (Fig. 4), with the highest yield during March to April. This variation in total RNA yield was probably due to extreme increases in certain transcripts related to development of germ cells (also see Liu et al. 2000,
Kusakabe et al. 2002a). For example, protamine is a nuclear protein that is synthesized only in the spermatid cells of the testis and substitutes for histones in sperm chromatin during the haploid phase of spermatogenesis (Gilmour \& Dixon 1972, Iatrou \& Dixon 1978). Protamine transcripts increased $300-400$ times in rainbow 
Table 2 Regression analysis among changes in serum steroid hormones, FSH-R, LH-R, StAR and steroidogenic enzyme transcript levels

\begin{tabular}{|c|c|c|c|c|}
\hline & 11-KT & $17,20 \beta-P$ & FSH-R & LH-R \\
\hline FSH-R & $P=\cdot 2375$, & $P=\cdot 1684,-$ & & \\
\hline LH-R & $P<\cdot 0001, r^{2}=0.32$ & $P<\cdot 0007, r^{2}=0.24$ & & \\
\hline StAR & $P<\cdot 0001, r^{2}=0.31$ & $P<\cdot 0001, r^{2}=0.31$ & $P<\cdot 0001, r^{2}=0.38$ & $P<\cdot 0001, r^{2}=0.61$ \\
\hline P450scc & $P<\cdot 0022, r^{2}=0.20$ & $P<\cdot 0117, r^{2}=0.14$ & $P<.0001, r^{2}=0.53$ & $P<\cdot 0001, r^{2}=0.65$ \\
\hline P450c17 & $P<\cdot 0001, r^{2}=0.30$ & $P<\cdot 0183, r^{2}=0 \cdot 13$ & $P<\cdot 0001, r^{2}=0.49$ & $P<\cdot 0001, r^{2}=0.62$ \\
\hline P45011 & $P<\cdot 9625,-$ & $P<\cdot 4500,-$ & $P<\cdot 0001, r^{2}=0.45$ & $P<\cdot 0001, r^{2}=0 \cdot 36$ \\
\hline $3 \beta-\mathrm{HSD}$ & $P<\cdot 1556,-$ & $P<\cdot 1474,-$ & $P<\cdot 0009, r^{2}=0.23$ & $P<\cdot 8778$, \\
\hline $11 \beta-H S D$ & $P<\cdot 0136, r^{2}=0.14$ & $P<\cdot 0005, r^{2}=0.25$ & $P<\cdot 0001, r^{2}=0.72$ & $P<\cdot 0001, r^{2}=0.62$ \\
\hline $20 \beta-H S D$ & $P<\cdot 0038, r^{2}=0.18$ & $P<\cdot 0002, r^{2}=0.29$ & $P<\cdot 1997,-$ & $P<\cdot 4356,-$ \\
\hline
\end{tabular}

trout testes during the stage of spermatogenesis when spermatids predominated (Kusakabe 2002). In this study, when real-time, quantitative RT-PCR data were normalized only to $18 \mathrm{~S}$, there was an apparent average fourfold decrease in abundance of both FSH-R and LH-R transcripts and steroidogenic protein transcripts between January and March, when both GSI and total RNA yield per testes peaked (data not shown), an effect probably due to the dilution of Leydig cell target mRNAs by mRNA, such as protamine, that are expressed in the multiplying and differentiating germ cells (Liu et al. 2000, Kusakabe et al. 2002a). To assess the functional importance of changes in transcript abundance (i.e. potential gonadal steroidogenic capacity of an individual animal), knowing the weight of sample tissue used for RNA extraction and the amount of total RNA extracted, we were able to estimate target transcript abundance within individual testes. We then normalized data to GSI, in order to account for gonad weight varying with fish body weight, as in the work of Kusakabe et al. (2002a, 2003).

Steroid profiles in this study were similar to previous studies (Baynes \& Scott 1985, Lou et al. 1986), with serum 11-KT increasing during mid-spermatogenesis to reach a peak a few months before serum 17,20 $\beta$-P increased. We hypothesized that expression of certain steroidogenic protein genes was pivotal in controlling steroid biosynthesis. Although there are some variations in the seasonal changes in expression of genes encoding the steroidogenic proteins, the patterns of steroid hormone secretion during the reproductive cycle appear to be largely regulated by changes in expression of particular steroidogenic protein genes that increased before prominent rises in plasma steroid hormones.

Previous work has shown that substantial in vitro $11-\mathrm{KT}$ production by coho salmon testis fragments occurs in response to short-term incubation with GTHs at least 1 month prior to a prominent increase in 11-KT levels in the plasma (Planas \& Swanson 1995). These results indicate that the steroidogenic machinery for $11-\mathrm{KT}$ production is in place some time before plasma levels increase, consistent with the results of this study. The increase in plasma 11-KT levels in male coho salmon coincided with an increase both in the sensitivity of the tissue to LH, and in 11-KT-synthesizing capacity (Planas \& Swanson 1995). In the present study in trout, 11-KT levels increased during a period of significant increases in LH-R transcripts. Gomez et al. (1999) demonstrated that in trout, plasma FSH levels were higher than plasma LH levels, were moderately increased during mid-spermatogenesis, and reached maximal levels during spermiation of rainbow trout, whereas plasma LH levels were low but steadily increased through spermatogenesis to reach a peak during the spermiation period.

In fish, very little information is available on the specific roles of FSH and LH in regulating androgen and 17,20ß-P production by the testis. In salmon, the relative potency of FSH and LH in stimulating in vitro steroid production by testis fragments at different stages of spermatogenesis were compared by Planas \& Swanson (1995). These authors demonstrated that the increase in plasma 11-KT levels coincided with an increase both in the sensitivity of the tissue to LH, and in 11-KT-synthesizing capacity. This may be due to increases in LH-R, because in the present study in trout, 11-KT levels increased during a period of significant increases in LH-R transcripts. Interestingly, the second increase in LH-R transcripts in trout occurred when plasma levels of 11-KT were maintained at maximum levels, plasma 17,20 $-\mathrm{P}$ increased, and spermiation became evident. A similar pattern in changes of plasma steroids in coho salmon was associated with increased sensitivity of the testis to LH for both 11-KT and $17,20 \beta-\mathrm{P}$ production, supporting the idea that increases in LH-R occur at that time. Although plasma levels of gonadotropins were not measured in the present study, Gomez et al. (1999) demonstrated that in rainbow trout, plasma LH levels were generally low (less than $1 \mathrm{ng} / \mathrm{ml}$ ) compared with FSH $(2-10 \mathrm{ng} / \mathrm{ml})$, and first detectable when spermatocytes were the predominant germ cell stage (comparable to the March samples in the present study). Plasma LH increased 15-fold as numbers of spermatids and spermatozoa increased, although maximum levels were still less than $1 \mathrm{ng} / \mathrm{ml}$ at spermiation. Thus, increases in 
plasma LH levels in trout during spermatogenesis appear to occur in parallel with increases in LH-R transcripts, and probably LH-R protein. Even though plasma FSH levels are substantially higher than LH during spermatogenesis in trout (Gomez et al. 1999), a number of studies in fish have shown that the LH receptor is specific for LH (reviewed by Bogerd et al. 2005), and autoradiography studies in salmon have localized an LH-specific receptor in Leydig cells (Miwa et al. 1991). Taken together, these data suggest that, in salmonids, a major regulatory point for steroid production by the testis could be increases in LH signaling, induction of LH receptor in Leydig cells of the testis, and increases in plasma LH.

In contrast to the pattern of LH-R gene expression, FSH-R transcripts fluctuated during spermatogenesis and were only 2-3-fold higher than initial levels toward the end of spermatogenesis. The initial rise in FSH-R transcripts (February-March) occurred prior to any significant change in LH-R gene expression and was associated with high meiotic activity in the testis (increase in spermatocytes and spermatids), but without a major change in plasma 11-KT levels. At this stage, Gomez et al. (1999) reported significant increases in plasma FSH levels in trout. Few data are available on specific functions of FSH in spermatogenesis in fish; however, studies suggest that FSH stimulates spermatogonial proliferation in trout (Loir 1999 ) and 11-KT production in vitro (Planas \& Swanson 1995). Furthermore, autoradiography studies in salmon localized FSH-R to presumed Sertoli cells, but could not determine whether Leydig cells contained FSH-R (Miwa et al. 1994). More recently, Schulz et al. (2003) reported that FSH also stimulates proliferation of Sertoli cells in African catfish. Thus, as in mammals, a major target of fish FSH appears to be Sertoli cells, and FSH plays important roles in regulating spermatogenesis. But, because fish FSH also stimulates androgen production, it is possible that either FSH-R is present in Leydig cells or other FSHinduced Sertoli cell products affect steroid biosynthesis. Thus, increases in transcripts for StAR and several steroidogenic enzymes that occur early in spermatogenesis in trout may be due to increases in FSH signaling (see discussion below).

Abundance of P450scc, P45011 $\beta$ and $11 \beta-H S D$ transcripts changed significantly but only moderately during the reproductive cycle. These three transcripts increased significantly in March, 3 months before serum 11-KT increased significantly. von Hofsten et al. (2002) reported a significant rise of transcripts for P450scc in Arctic char testes when plasma 11-KT levels were high in vivo. This difference may be due to the different ways of quantifying data, since the P450scc mRNA levels of Arctic char were presented on a unit RNA base, whereas the P450scc mRNA levels in this study were normalized by total testes RNA and GSI (Fig. 6). Although the magnitude of changes in transcript levels of P45011 $\beta$ was lower (threefold increase) than seen in the previous study, where transcript levels were determined by Northern blotting (Kusakabe et al. 2002a), transcript levels were highest when serum 11-KT levels increased significantly. FSH-R and LH-R transcript levels exhibited moderately to strongly significant linear relationships with P450scc, $\mathrm{P} 45011 \beta$ and $11 \beta-\mathrm{HSD}$ transcripts, suggesting that the expression of the P450scc, P45011 $\beta$ and $11 \beta$-HSD genes is at least partially regulated by FSH and/or LH. It appears that there is a distinct gender difference with regard to the changes in $3 \beta-H S D$ and $20 \beta-H S D$ mRNA levels during gametogenesis in rainbow trout. In male rainbow trout, testicular $3 \beta-H S D$ mRNA levels showed a prominent 8-9-fold increase to peak levels in the early stage of mid-spermatogenesis (March and April), followed by a rapid decline to levels $2-3$-fold higher than the initial sample for the remainder of the study. In contrast, ovarian $3 \beta-H S D$ mRNA levels in female rainbow trout increased during late vitellogenesis and post-ovulation (Nakamura et al. 2005). These observations imply that expression of the testicular $3 \beta-\mathrm{HSD}$ gene may be regulated differently from those for other key steroidogenic enzymes, although the functional significance of the rapid increase of testicular $3 \beta-H S D$ transcripts during mid-spermatogenesis is still unclear. In female rainbow trout, $20 \beta-H S D$ mRNA levels significantly increased sevenfold during the late reproductive stages (Nakamura et al. 2005). Ovarian 20ß-HSD transcripts in ayu (Tanaka et al. 2002) and tilapia (Senthilkumaran et al. 2002) also showed a distinct increase during late oogenesis stages. In contrast, $20 \beta-\mathrm{HSD}$ transcripts in rainbow trout testes appeared to have an inverse relationship with seasonal serum 17,20 $\beta$-P levels, $20 \beta-H S D$ mRNA levels decreasing during late spermatogenesis when serum 17,20 $\beta$-P levels peaked. One possible explanation for the weak relationship is that there may be more than one type of $20 \beta$-HSD in some teleosts. In male amago salmon, an in vitro study demonstrated that sperm converted $17 \alpha$-hydroxyprogesterone to $17,20 \beta-\mathrm{P}$ in rainbow trout (Ueda et al. 1984, Sakai et al. 1989), suggesting the existence of $20 \beta-H S D$ enzyme in the salmonid sperm. However, Vizziano et al. (1996) reported 20ß-HSD activity in nonflagellated germ cells obtained from early spermatogenic rainbow trout testes, although serum $17,20 \beta-P$ levels are very low at this stage. In this study, 20ß-HSD mRNA levels were high during the midspermatogenesis stages, whereas levels during late spermatogenesis were almost nondetectable. Histologic analysis showed that mid-spermatogenic testes are occupied with a considerable proportion of nonflagellated germ cells (Fig. 2). Therefore, the $20 \beta-\mathrm{HSD}$ mRNAs detected in the rainbow trout testes may be derived from nonflagellated germ cells. Further investigation is required to clarify the regulation of $20 \beta-\mathrm{HSD}$ associated with testicular $17,20 \beta-\mathrm{P}$ production. All in all, it appears that the moderate changes in P450scc, P45011 $\beta, 11 \beta-H S D$, $3 \beta-$ HSD and $20 \beta-$ HSD transcripts may have only minor effects on the changes in seasonal steroid production. 
StAR mRNA correlated moderately with serum 11 -KT levels $\left(r^{2}=0 \cdot 31, P<0 \cdot 0001\right)$. Of all the transcripts measured, the 10-fold increase in StAR mRNA was the greatest change observed. During the later stages of spermatogenesis, StAR transcripts increased significantly, corresponding to the increases of serum sex-steroid levels. These results suggest that StAR abundance at least partially determines the levels of steroid production during spermatogenesis in rainbow trout. Previous mammalian studies have demonstrated an induction of StAR protein by LH treatment in rat Leydig cells (Luo et al. 1998). Interestingly, there was a significant linear relationship between LH-R and StAR mRNA levels $\left(r^{2}=0 \cdot 61\right.$, $P<0 \cdot 0001)$, which was higher than that of FSH-R and StAR mRNA $\left(r^{2}=0 \cdot 38, P<0 \cdot 0001\right)$. These results, along with data from other studies on plasma FSH and LH levels, suggest that expression of the StAR gene may be under the control of FSH during early stages of spermatogenesis, and of $\mathrm{LH}$ during the later stages of spermatogenesis.

Like StAR transcripts, P450C17 transcripts had a moderately linear relationship with serum 11-KT levels $\left(r^{2}=0 \cdot 30, P=0 \cdot 0001\right)$. Both StAR and P450C17 started increasing in March and April when spermatocyte abundance started to increase (Fig. 5). P450C17 is a single microsomal enzyme that catalyzes two distinct steroid biosynthesis activities, 17 $\alpha$-hydroxylase and 17,20-lyase. Phosphorylation of P450C17 and the presence of cytochrome b5 are important factors determining whether the enzyme has 17,20-lyase activity (Katagiri et al. 1995, Zhang et al. 1995). These factors partly explain the tissue-specific differences in P450C17 activities between adrenal gland and gonads (Miller et al. 1997). As rainbow trout P450C17 also has two distinct steroid biosynthetic activities (Sakai et al. 1992), the relative enzymatic activity of $17 \alpha$-hydroxylase and 17,20-lyase probably regulates the biosynthesis of androgens and progestogen. The lack of $17,20 \beta-\mathrm{P}$ production during the early and midspermatogenesis stages, despite the presence of $20 \beta-H S D$ mRNA (this study) and evidence of protein (Vizziano et al. 1996) in the testes, may be due to high C17-C20 lyase activity resulting in low availability of the immediate precursor for 17,20 $\beta-\mathrm{P}, 17 \alpha$-hydroxyprogesterone. Knowledge of the regulation of the enzymatic activities of P450C17 is important to understand the mechanisms of testicular $17,20 \beta-\mathrm{P}$ production in teleosts.

This study provides an overall picture of changes in steroidogenic enzyme gene expression changes during spermatogenesis and their relationships to steroid production. The patterns of steroid hormone secretion during the reproductive cycle appear to be largely regulated by changes in expression of genes encoding StAR, P450C17, and gonadotropin receptors. Expression of genes encoding various steroidogenic enzymes increased before prominent rises in levels of plasma steroid hormones that were presumably initiated by FSH and/or LH signals.
Planas et al. (1997) reported that two intracellular signaling pathways, cAMP/protein kinase A and protein kinase $\mathrm{C} / \mathrm{Ca}^{2+}$, mediate the effects of FSH and $\mathrm{LH}$ on ovarian steroidogenesis in brook trout. How these signaling pathways affect gene expression of steroidogenic enzymes and related factors has not yet been clarified. Experimental approaches will be required for further understanding of the regulation of steroidogenesis at the level of gene expression, such as analyzing the effects on expression of genes encoding these proteins through in vitro tissue culture with GTHs.

\section{Acknowledgements}

Jon Dickey (National Marine Fisheries Service), Kim Garrett (University of Otago), Ken Miller (University of Otago) and Gerald Stokes (University of Otago) provided excellent technical assistance. Dr Munetaka Shimizu (University of Washington) provided statistical assistance.

\section{Funding}

This work was supported by the National Research Initiative Competitive Grant no. 2003-35203-13602 from the USDA Cooperative State Research, Education, and Extension Service (to G Y), Bonneville Power Administration Project no. 93-056 (to P S) and a Japan Society for the Promotion of Science Fellowship (to $\mathrm{M} \mathrm{K}$ ). The authors declare that there is no conflict of interest that would prejudice the impartiality of this scientific work.

\section{References}

Aspden WJ, Rodgers RJ, Stocco DM, Scott PT, Wreford NG, Trigg TE, Walsh J \& D'Occhio MJ 1998 Changes in testicular steroidogenic acute regulatory (StAR) protein, steroidogenic enzymes and testicular morphology associated with increased testosterone secretion in bulls receiving the luteinizing hormone releasing hormone agonist deslorelin. Domestic Animal Endocrinology $15227-238$.

Baynes SM \& Scott AP 1985 Seasonal variations in parameters of milt production and in plasma concentration of sex steroids of male rainbow trout (Salmo gairdneri). General and Comparative Endocrinology 57 150-160.

Bobe J, Nguyen T \& Jalabert B 2004 Targeted gene expression profiling in the rainbow trout (Oncorhynchus mykiss) ovary during maturational competence acquisition and oocyte maturation. Biology of Reproduction 71 73-82.

Bogerd J, Granneman JC, Schulz RW \& Vischer HF 2005 Fish FSH receptors bind LH: how to make the human FSH receptor to be more fishy? General and Comparative Endocrinology 142 34-43.

Bustin SA 2002 Quantification of mRNA using real-time reverse transcription PCR (RT-PCR): trends and problems. Journal of Molecular Endocrinology 29 23-39.

Doody KJ, Lephart ED, Stirling D, Lorence MC, Magness RR, McPhaul MJ \& Simpson ER 1990a Expression of mRNA species encoding steroidogenic enzymes in the rat ovary. Journal of Molecular Endocrinology 6 153-162. 
Doody KJ, Lorence MC, Mason JI \& Simpson ER 1990b Expression of messenger ribonucleic acid species encoding steroidogenic enzymes in human follicles and corpora lutea throughout the menstrual cycle. Journal of Clinical Endocrinology and Metabolism 70 1041-1045.

García-Hernández MP, Koide Y, Díaz MV \& Kawauchi H 1997 Isolation and characterization of two distinct gonadotropins from the pituitary gland of Mediterranean yellowtail, Seriola dumerilii (Risso, 1810). General and Comparative Endocrinology 106 389-399.

Gilmour RS \& Dixon GH 1972 Biosynthesis of protamine in trout testis. Journal of Biological Chemistry 247 4621-4627.

Gomez JM, Weil C, Ollitrault M, Le Bail PY, Breton B \& Le Gac F 1999 Growth hormone (GH) and gonadotropin subunit gene expression and pituitary and plasma changes during spermatogenesis and oogenesis in rainbow trout (Oncorhynchus mykiss). General and Comparative Endocrinology 113 413-428.

Grier HJ 1981 Cellular organization of the testis and spermatogenesis in fishes. American Zoologist 21 345-357.

Guan G, Tanaka M, Todo T, Young G, Yoshikuni M \& Nagahama Y 1999 Cloning and expression of two carbonyl reductase-like $20 \beta$-hydroxysteroid dehydrogenase cDNAs in ovarian follicles of rainbow trout (Oncorhynchus mykiss). Biochemical and Biophysical Research Communications 255 123-128.

Iatrou K \& Dixon GH 1978 Protamine messenger RNA: its life history during spermatogenesis in rainbow trout. Federation Proceedings 37 2526-2533.

Kagawa H, Takano K \& Nagahama Y 1981 Correlation of plasma estradiol-17 $\beta$ and progesterone levels with ultrastructure and histochemistry of ovarian follicles in the white-spotted char, Salvelinus leucomaenis. Cell and Tissue Research 218 315-329.

Katagiri M, Kagawa N \& Waterman MR 1995 The role of cytochrome b5 in the biosynthesis of androgens by human P450c17. Archives of Biochemistry and Biophysics 317 343-347.

King HR \& Young G 2001 Milt production by non-spermiating male Atlantic salmon (Salmo salar) after injection of a commercial gonadotropin releasing hormone analog preparation,

$17 \alpha$-hydroxyprogesterone or $17 \alpha, 20 \beta$-dihydroxy-4-pregnen-3-one, alone or in combination. Aquaculture 193 179-195.

Kobayashi T, Nakamura M, Kajiura-Kobayashi H, Young G \& Nagahama Y 1998 Immunolocalization of steroidogenic enzymes (P450scc, P450C17, P450 arom, and 3 $\beta-\mathrm{HSD}$ ) in immature and mature testes of rainbow trout (Oncorhynchus mykiss). Cell and Tissue Research 292 573-577.

Koide Y, Itoh H \& Kawauchi H 1993 Isolation and characterization of two distinct gonadotropins, GTHI and GTHII, from bonito (Katsuwonus plelamis) pituitary glands. International Journal of Peptide and Protein Research 41 52-65.

Kumar RS, Ijiri S \& Trant JM 2000 Changes in the expression of genes encoding steroidogenic enzymes in the channel catfish (Ictalurus punctatus) ovary throughout a reproductive cycle. Biology of Reproduction 63 1676-1682.

Kusakabe M 2002 Steroidogenic acute regulatory protein (StAR) and steroidogenic enzymes in rainbow trout (Oncorhynchus mykiss): cDNA cloning and expression during spermatogenesis. Thesis, University of Otago, Dunedin, New Zealand.

Kusakabe M, Kobayashi T, Todo T, Lokman PM, Nagahama Y \& Young G 2002a Molecular cloning and expression during spermatogenesis of a cDNA encoding testicular 11ß-hydroxylase $(\mathrm{P} 45011 \beta)$ in rainbow trout (Oncorhynchus mykiss). Molecular Reproduction and Development 62 456-469.

Kusakabe M, Todo T, McQuillan HJ, Goetz FW \& Young G 2002b Characterization and expression of steroidogenic acute regulatory protein and MLN64 cDNAs in trout. Endocrinology 143 2062-2070.

Kusakabe M, Nakamura I \& Young G 2003 11ß-Hydroxysteroid dehydrogenase complementary deoxyribonucleic acid in rainbow trout: cloning, sites of expression, and seasonal changes in gonads. Endocrinology 144 2534-2545.
Liu S, Govoroun M, D'Cotta H, Ricordel MJ, Lareyre JJ, McMeel OM, Smith T, Nagahama Y \& Guiguen Y 2000 Expression of cytochrome P45011 (11 $\beta$-hydroxylase) gene during gonadal sex differentiation and spermatogenesis in rainbow trout, Oncorhynchus mykiss. Journal of Steroid Biochemistry and Molecular Biology 75 291-298.

Loir M 1999 Spermatogonia of rainbow trout. II. In vitro study of the influence of pituitary hormones, growth factors, and steroids on mitotic activity. Molecular Reproduction and Development 53 434-442.

Lou SW, Aida K, Hanyu I, Sakai K, Nomura M, Tanaka M \& Tazaki S 1986 Endocrine profiles in the males of a twice-annually spawning strain of rainbow trout, Salmo gairdneri. General and Comparative Endocrinology 64 212-219.

Luo L, Chen H, Stocco DM \& Zirkin BR 1998 Leydig cell protein synthesis and steroidogenesis in response to acute stimulation by luteinizing hormone in rats. Biology of Reproduction 59 263-270.

Miller WL, Auchus RJ \& Geller DH 1997 The regulation of 17,20 lyase activity. Steroids 62 133-142.

Miura T, Yamauchi K, Takahashi H \& Nagahama Y 1991 Hormonal induction in vitro of all stages of spermatogenesis in the male Japanese eel (Anguilla japonica). PNAS 88 5774-5778.

Miwa S, Yan L \& Swanson P 1994 Localization of two gonadotropin receptors in the salmon gonad by in vitro ligand autoradiography. Biology of Reproduction 50 629-642.

Nagahama Y 1994 Endocrine regulation of gametogenesis in fish. International Journal of Developmental Biology 38 217-229.

Nakamura I, Evans CJ, Kusakabe M \& Young G 2005 Changes in steroidogenic enzyme and steroidogenic acute regulatory protein messenger RNAs in ovarian follicles during ovarian development of rainbow trout (Oncorhynchus mykiss). General and Comparative Endocrinology 144 224-231.

Oba Y, Hirai T, Yoshiura Y, Yoshikuni M, Kawauchi H \& Nagahama Y 1999a Cloning, functional characterization, and expression of a gonadotropin receptor cDNA in the ovary and testis of amago salmon (Oncorhynchus rhodurus). Biochemical and Biophysical Research Communications 263 584-590.

Oba Y, Hirai T, Yoshiura Y, Yoshikuni M, Kawauchi H \& Nagahama Y $1999 b$ The duality of fish gonadotropin receptors: cloning and functional characterization of a second gonadotropin receptor cDNA expressed in the ovary and testis of amago salmon (Oncorhynchus rhodurus). Biochemical and Biophysical Research Communications 265 366-371.

Okada T, Kawazoe I, Kimura S, Sasamoto Y, Aida K \& Kawauchi H 1994 Purification and characterization of gonadotropin I and II from pituitary glands of tuna (Thunnus obesus). International Journal of Peptide and Protein Research 43 69-80.

Planas J \& Swanson P 1995 Maturation-associated changes in the response of the salmon testis to the steroidogenic actions of gonadotropins (GTH I and GTH II) in vitro. Biology of Reproduction 52 697-704.

Planas J, Goetz FW \& Swanson P 1997 Stimulation of brook trout ovarian steroidogenesis by gonadotropins I and II is mediated by the cyclic adenosine $3^{\prime}, 5^{\prime}$-monophosphate/protein kinase A pathway. Biology of Reproduction 57 647-654.

Prat F, Sumpter JP \& Tyler CR 1996 Validation of radioimmunoassays for two salmon gonadotropins (GTH I and GTH II) and their plasma concentrations throughout the reproductive cycle in male and female rainbow trout (Oncorhynchus mykiss). Biology of Reproduction 54 1375-1382.

Richards JS 1994 Hormonal control of gene expression in the ovary. Endocrine Reviews 15 725-751.

Sakai N, Ueda H, Suzuki N \& Nagahama Y 1989 Steroid production by amago salmon (Oncorhynchus rhodurus) testes at different developmental stages. General and Comparative Endocrinology $75231-240$.

Sakai N, Tanaka M, Adachi S, Miller WL \& Nagahama Y 1992 Rainbow trout cytochrome P-450c17 (17 $\alpha$-hydroxylase/ 
17,20-lyase). cDNA cloning, enzymatic properties and temporal pattern of ovarian P-450c17 mRNA expression during oogenesis. FEBS Letters 301 60-64.

Sakai N, Tanaka M, Takahashi M, Fukada S, Mason JI \& Nagahama Y 1994 Ovarian 3 $\beta$-hydroxysteroid dehydrogenase/ $\triangle 5$-4-isomerase of rainbow trout: its cDNA cloning and properties of the enzyme expressed in a mammalian cell. FEBS Letters 350 309-313.

Schulz RW \& Miura T 2002 Spermatogenesis and its endocrine regulation. Fish Physiology and Biochemistry 26 43-56.

Schulz RW, van Dijk W \& Bogerd J 2003 Sertoli cell proliferation and FSH signaling in African catfish, Clarias garipinus. Fish Physiology and Biochemistry 28 223-224.

Senthilkumaran B, Sudhakumari CC, Chang XT, Kobayashi T, Oba Y, Guan G, Yoshiura Y, Yoshikuni M \& Nagahama Y 2002 Ovarian carbonyl reductase-like $20 \beta$-hydroxysteroid dehydrogenase shows distinct surge in messenger RNA expression during natural and gonadotropin-induced meiotic maturation in nile tilapia. Biology of Reproduction 67 1080-1086.

Stocco DM 2000 The role of StAR protein in steroidogenesis: challenges for the future. Journal of Endocrinology 164 247-253.

Suzuki K, Kawauchi H \& Nagahama Y 1988 Isolation and characterization of two distinct gonadotropins from chum salmon pituitary glands. General and Comparative Endocrinology 71 292-301.

Swanson P, Bernard M, Nozaki M, Suzuki K, Kawauchi H \& Dickhoff WW 1989 Gonadotropins I and II in juvenile coho salmon. Fish Physiology and Biochemistry 7 169-176.

Swanson P, Suzuki K, Kawauchi H \& Dickhoff WW 1991 Isolation and characterization of two coho salmon gonadotropins, GtH I and GtH II. Biology of Reproduction 44 29-38.

Takahashi M, Tanaka M, Sakai N, Adachi S, Miller WL \& Nagahama Y 1993 Rainbow trout ovarian cholesterol side-chain cleavage cytochrome P450 (P450scc). cDNA cloning and mRNA expression during oogenesis. FEBS Letters 319 45-48.

Tanaka H, Kagawa H, Okuzawa K \& Hirose K 1993 Purification of gonadotropins (Pm GTH I and II) from red seabream (Pagrus major) and development of a homologous radioimmunoassay for Pm GTH II. Fish Physiology and Biochemistry 10 409-418.

Tanaka M, Telecky TM, Fukada S, Adachi S, Chen S \& Nagahama Y 1992 Cloning and sequence analysis of the cDNA encoding P-450 aromatase ( $\mathrm{P} 450$ arom) from a rainbow trout (Oncorhynchus mykiss) ovary; relationship between the amount of $\mathrm{P} 450$ arom mRNA and the production of oestradiol-17 $\beta$ in the ovary. Journal of Molecular Endocrinology 8 53-61.

Tanaka M, Nakajin S, Kobayashi D, Fukada S, Guan G, Todo T, Senthilkumaran B \& Nagahama Y 2002 Teleost ovarian carbonyl reductase-like $20 \beta$-hydroxysteroid dehydrogenase: potential role in the production of maturation-inducing hormone during final oocyte maturation. Biology of Reproduction 66 1498-1504

Ueda H, Young G, Crim LM, Kambegawa A \& Nagahama Y 1983 $17 \alpha, 20 \beta$-Dihydroxy-4-pregnen-3-one: plasma levels during sexual maturation, and in vitro production by the testes of amago salmon (Oncorhynchus rhodurus) and rainbow trout (Salmo gairdneri). General and Comparative Endocrinology 51 106-112.

Ueda H, Kambegawa A \& Nagahama Y 1984 In vitro 11-ketotestosterone and 17 $\alpha, 20 \beta$-dihydroxy-4-pregnen-3-one production by testicular fragments and isolated sperm of rainbow trout, Salmo gairdneri. Journal of Experimental Zoology $231435-439$.

Ueda H, Kambegawa A \& Nagahama Y 1985 Involvement of gonadotrophin and steroid hormones in spermiation in the amago salmon, Oncorhynchus rhodurus, and goldfish, Carassius auratus. General and Comparative Endocrinology 59 24-30.

Van der Kraak G, Suzuki K, Peter RE, Itoh H \& Kawauchi H 1992 Properties of common carp gonadotropin I and gonadotropin II. General and Comparative Endocrinology 85 217-229.

Vizziano D, Fostier A, Le Gac F \& Loir M 1996 20ß-hydroxysteroid dehydrogenase activity in nonflagellated germ cells of rainbow trout testis. Biology of Reproduction 54 1-7.

von Hofsten J, Karlsson J, Jones I \& Olsson PE 2002 Expression and regulation of fushi tarazu factor-1 and steroidogenic genes during reproduction in Arctic char (Salvelinus alpinus). Biology of Reproduction 67 1297-1304.

Weltzien FA, Norberg B \& Swanson P 2003 Isolation and characterization of FSH and $\mathrm{LH}$ from pituitary glands of Atlantic halibut (Hippoglossus hippoglossus L.). General and Comparative Endocrinology 131 97-105.

Young G, Adachi S \& Nagahama Y 1986 Role of ovarian thecal and granulosa layers in gonadotropin-induced synthesis of a salmonid maturation-inducing substance (17 $\alpha, 20 \beta$-Dihydroxy-4-pregnen-3-one). Developmental Biology $1181-8$.

Zhang LH, Rodriguez H, Ohno S \& Miller WL 1995 Serine phosphorylation of human P450c17 increases 17,20-lyase activity: implications for adrenarche and the polycystic ovary syndrome. PNAS 92 10619-10623.

Received in final form 17 February 2006

Accepted 3 March 2006

Made available online as an Accepted Preprint 13 March 2006 